\title{
Theoretical Analysis of Internet Ideological and Political Education for College Students from the Perspective of Internet Interpersonal Interaction
}

\author{
Huang Xuewen \\ School of Marxism, Zhejiang University \\ Hangzhou 310053, China
}

\begin{abstract}
In order to improve the effectiveness of Ideological and political education for college students in the Internet era, we can start from the perspective of Internet interpersonal interaction, and study the Internet ideological and political education for college students so as to understand the current situation and existing problems of Ideological and political education of college students on the internet, thereby providing references for ideological and political educators. We should help students develop comprehensively and coordinately, and improve their ideological and political quality.
\end{abstract}

Keywords-College students; Interpersonal interaction; Ideological and Political Education; Internet

\section{INTRODUCTION}

With the development of cyber technology, great changes have taken place in the form of human communication. There is no doubt that Internet interpersonal interaction is a brandnew practice of human communication in the contemporary and future. The influence and impact of Internet interpersonal interaction on the way of social communication and social life present a collective form. It integrates the practical forms of communication that affect the real society from the aspects of relationship, activity, structure and mechanism, demonstrating its great practical significance and theoretical value, and objectively restricts, promotes and decides that Internet ideological and political education must regard the issue of Internet interpersonal interaction as the basic field of vision for its own research. Therefore, the theoretical innovation and practical application of Internet ideological and political education shall not be separated and must be carried out around the basic horizon of Internet interpersonal interaction. At present, domestic scholars have done a lot of research on Internet Ideological and political education, but few researchers have studied it from the perspective of Internet interpersonal interaction. Network interpersonal interaction has the advantages of equal and mutual assistant interpersonal interaction mode, instant and effective information dissemination mode, multiple and abundant information, which makes ideological and political education practice has become possible on the Internet interactive platform. Moreover, taking Internet interpersonal interaction as the basic horizon of Internet ideological and political education research is also in line with the current development of the Internet and the realistic needs of Internet ideological and political education research.

\section{RESEARCH BACKGROUND}

\section{A. Internet era is in urgent need of Internet ideological and political education}

Network technology originated in the West, and Western countries also paid attention to the research on the impact of the development of the Internet on humans, network ethics, network morals and other aspects in a relatively earlier time and achieved certain results. First of all, from the theoretical research point of view, a large number of theoretical works have been published. The more famous one is Being Digital by Nicholas Negroponte [1],Ethical Aspects of Information Technology by Spinello [2],From the interface to cyberspace by Michael Heim [3],The Psychology of The Internet by Patricia Wallace[4], The Hacker Ethic and the Spirit of the Information Age by Pekka Himanen[5], Becoming modern: idividual change in six developing courntries by Alex Inkeles [6], etc., these books mainly discuss the impact of the development of the Internet on people, including a large number of content about network ethics and morals. Secondly, Western countries attach great importance to education in network ethics and network morals. More and more universities offer a variety of computer ethics, network ethics courses or special lectures, such as Duke University, the "ethics and the Internet" course. The University of Delaware states that if a freshman wants to use the campus network, he or she must first receive training on the network ethics knowledge organized by the school, and then pass the assessment before qualifying to use the campus network. Finally, it attaches great importance to the legislation of computer networks, and has enacted a large number of network laws and regulations and codes of conduct, such as the US Children's Internet Privacy Protection Act [7], Germany's "Telecom Service Data Protection Law" [8], British Prohibition of abused using computing law [9]. These practices and research results abroad are worth learning and learning from. 


\section{B. Current college students are in frequent contact with the network environment}

According to the 38th National Statistical Report on Internet Development published by China Internet Information Center (CNNIC) [10] in August 2016, by June 2016, the number of Internet users in China had reached 710 million, and the penetration rate of Internet reached $51.7 \%$, which exceeded the global average by 3.1 percentage points. In terms of age composition, Chinese netizens are still mainly between 10-39 years old, accounting for $74.7 \%$ of the total, of which $20-29$ years old netizens account for the highest proportion, reaching $30.4 \%$. At present, college students are the most frequently contacted teenagers with the Internet. All kinds of resources on the Internet will inevitably affect the thoughts and actions of the majority of young college students. On the one hand, the Internet has continuously broadened the cognitive horizons of College students, helped them to keep abreast of the latest developments and grasp the latest progress of public opinion, stimulated the development of individual initiative, and further highlighted the principles of freedom, equality, difference and coexistence. Every individual can freely express his or her opinions and satisfy his or her eagerness to the right of speak. Realizing the transformation from passive recipients to active communicators [11]. On the other hand, the information on the Internet is mixed, and college students are still in an incomplete stage of physical and mental maturity. Their ability to identify information is not good enough. They are easily attracted and confused by wrong ideas, resulting in some wrong thoughts and behaviors. All these have put forward new requirements for ideological and political educators in Colleges and universities. How to carry out network ideological and political education of college students has become an important and urgent research topic.

\section{CURRENT GENERAL SITUATION OF INTERNET IDEOLOGICAL AND POLITICAL EDUCATION FOR COLLEGE STUDENTS}

Generally speaking, the ideological situation of college students in our country is good. They are very concerned about the future of the motherland. They realize that the development of the country and the future of the individual are closely linked. In life and study, they are active in thinking, have a prominent sense of self-esteem and have a strong desire for growth. However, the opportunities and challenges of network ideological and political education for college students coexist in the new media age. The network has the characteristics of fast dissemination, large amount of information, rich content, wide coverage and strong interaction, which brings many opportunities to the ideological and political education of College students. The openness of the network and the large capacity of information in the network world have broadened the channels for college students to acquire knowledge and information, expanded the space of Ideological and political education, and diversified the means of Ideological and political education for college students. But the network is also full of all kinds of information, focusing on different national views, values, religious views, moral views, which has a lot of negative effects on the identification ability, self-control ability of immature College students. Such as the network carrier construction lags behind [14], the ideological and political educators' network awareness is not strong, the work form is simplified. The information quality varies greatly, the University lacks the supervisory ability. At present, many colleges and universities actively construct campus network and ideological and political education thematic network, attach importance to updating the dynamic information inside and outside the school, timely release of information and news, and focus on carrying out rich and colorful activities of network culture construction. However, the website is rigid in form, lacks interaction and communication with students, and lacks attractiveness and attractiveness. Influence has greatly weakened the effectiveness of network ideological and political education [15].

\section{The DEVElopMent of COLLEge Students' Network IDEOLOGICAL AND POLITICAL EDUCATION FROM THE PERSPECTIVE OF NETWORK INTERPERSONAL INTERACTION}

College students' Network Ideological and political education is a new method of Ideological and political education designed on the basis of making full use of computer network, multimedia technology and modern communication technology, and closely combining the cognitive characteristics of contemporary college students. Network interpersonal interaction is a new form of communication practice, which takes e-mail, blog, micro-blog, micro-mail, QQ and other interactive tools as the carrier. With its advantages of equal and mutual assistance interpersonal communication mode, instant and effective way of information dissemination, multiple and abundant mass information, it makes ideological and political education practice activities in the online interactive platform possible. On the one hand, network interpersonal interaction is conducive to the implementation of College Students' ideological and political education on the network. It spreads positive energy through network interaction, thus promoting the healthy growth of College students. On the other hand, because the network carrier has the disadvantages of lacking authenticity and authority. For the ideological and political education of college students, there are challenges in guiding mainstream values, shaping a healthy personality, and enhancing moral responsibility. From the perspective of network interpersonal interaction, the methods of Ideological and political education of college students can be carried out in the following aspects:

(1) Construct a special website for college students' network ideological and political education. Fully create a website that meets the age and psychological acceptance of college students and spread positive values and beliefs. For example, E-class and other websites that allow college students to fully engage in interpersonal interactions can replace the content of single and boring content in the ideological and political education classroom. University students can also work with teachers, instructor and classmates on the E-class website, conducting equal and friendly exchanges, fully explore what they think, and gradually establish correct values.

(2) To create attractive new media Wechat subscription in Colleges and universities. Nowadays, the attraction of traditional media such as school newspaper and campus TV station to college students has been weakened. Mobile phone is 
an important information outlet for the future development of the network. Through mobile client platform, we can create a new media public with an age and appeal that is close to the university's own needs. Wechat subscription. Through the channels of WeChat, Zhihu.com, Sina Microblog and other channels to transmit information on Ideological and political work, we can make the ideological and political work of colleges and universities more extensive, faster, larger capacity, higher efficiency, and make its impact on college students more in-depth.

(3) All the ideological and political teams in colleges and universities should participate in the ideological and political education of college students. Ideological and political education in colleges and universities is not only the responsibility of teachers and counselors in the ideological and political class. All faculty and staff in colleges and universities have the responsibility of "all staff to educate students". The theory of interpersonal interaction focuses on the relationship between individuals and others. This view lays a theoretical foundation for the construction of an interpersonal interactive ideological and political education model. The ideological and political team in colleges and universities should strive to improve its theoretical level and guide college students to be the firm believers, active communicators, and model practitioners of the socialist core values.

\section{THE SignifiCANCE OF IDEOLOGICAL AND POLITICAL EDUCATION FOR COLLEGE STUDENTS FROM THE PERSPECTIVE OF NETWORK INTERPERSONAL INTERACTION}

From the perspective of network interpersonal interaction, the study of College Students' ideological and political education has profound theoretical and practical significance at this stage.

\section{A. Theoretical significance}

First, research on the network ideological and political education of college students, expand the research horizon and theoretical system of ideological and political education in the network age, and conform to the modern development pace of the discipline construction of ideological and political education. The research on the basic theory of network ideological and political education will reveal more clearly the development trend of socialization, individualization, life and institutionalization of network ideological and political education.

Secondly, the research on the network ideological and political education of college students from the perspective of interpersonal interaction in the network is not only a must to establish a new theoretical analysis framework for the study of network ideological and political education, but also a major theoretical innovation on the traditional interpersonal interaction theory. The research of network interpersonal interaction itself also constitutes the core content of the basic theoretical research of network ideological and political education. With the further strengthening of the relationship between network information technology and social interaction, the research results of the network interpersonal interaction theory will directly become the basic guiding theory for us to examine and analyze many phenomena of network social politics, economy and culture. This is undoubtedly of great significance for the future research of network ideological and political education.

\section{B. Practical significance}

Firstly, from the perspective of network interpersonal interaction to study the network ideological and political education of College students, reflects and conforms to the development trend of Ideological and political education activities, and enhances the effectiveness of network ideological and political education. The research on the theory of network ideological and political education deeply analyses the essence and characteristics of network, network culture, network society and ideological and political education in it. It is of great significance to comprehensively and profoundly understanding the social orientation of Ideological and political education activities and to renew the concept, system, content and means of Ideological and political education.

Secondly, from the perspective of network interpersonal interaction to study the network ideological and political education of college students is conducive to strengthening the guidance of network public opinion of Ideological and political education. In the era of network information, information dissemination presents the characteristics of multi-terminal interconnection, diversified publishing methods, information dissemination separated from traditional institutions, information fragmentation, and information understanding in incomplete context. Everyone can express their views in cyberspace, thus forming a strong information penetration and strong public opinion guidance.

\section{CONCLUSION}

Studying the network ideological and political education of college students from the perspective of network interpersonal interaction will help to play the role of network interpersonal interaction in disseminating positive social energy, strengthen the function of Ideological and political education in Colleges and universities, in the process of improving the effectiveness of ideological and political education, strengthening the moral responsibility consciousness of college students and cultivating independent personality have certain guiding significance for both theory and reality. 


\section{REFERENCES}

[1] Nicholas Negroponte, Being Digital [M]. Beijing: Publishing House of Electronics Industry, 1997.237.(In Chinese)

[2] Richard A. Spinello, Ethical Aspects of Information Technology[M]. Beijing: Central Compilation \& Translation Press, 1999. (In Chinese)

[3] Michael Heim, From the interface to cyberspace[M].Shanghai: Shanghai scientific and technology publishers,2000. (In Chinese)

[4] Patricia Wallace ,The Psychology of The Internet[M].Beijing: China Light Industry Press.2001. (In Chinese)

[5] Pekka Himanen, The Hacker Ethic and the Spirit of the Information Age[M].Beijing: China Citic Press.2002. (In Chinese)

[6] Alex Inkeles, Smith, David H, Becoming modern: Individual change in six developing countries[M].Beijing: China Renmin University press. 1992. (In Chinese)

[7] Xin xin. Laws alone cannot save online children [J]. Foreign social science, 2004 (6): 112-112. (In Chinese)

[8] Han chifeng. Obligations and responsibilities of Internet service providers -- from the perspective of the German telecom media act [J]. Journal of law, 2014, 35(10):22-29. (In Chinese)

[9] Liu wei. Introduction to foreign cybercrime prevention and control system [J]. Information network security, 2005(6):66-68. (In Chinese)

[10] CNNIC released the 38th statistical report on China's Internet development [J]. Information network security,2016,(08):89.(In Chinese)

[11] Ma jianqing, Gu qingqing. Thoughts on education of network ideology and politics in innovative universities in the "micro" era [J]. Education of thought theory, 2014(8):77-80. (In Chinese)

[12] Ma jianqing, Chen zengyan. An analysis of xi jinping's important discourse on the social responsibility of youth [J]. Mao zedong, Deng xiaoping theory research,2016,(10):18-22. (In Chinese)

[13] Zhu yanyan. Research on the influence of new media on education of college students' ideological politics and countermeasures [D]. Xinyang normal university, 2015. (In Chinese)

[14] Cao wenbo. The theory of college students' network ideological and political education, 2013(26):64-65. (In Chinese)

[15] Lei tiantian. An innovative study on the ideological and political thinking of college students from the perspective of communication theory [D]. Chang 'an university, 2014. (In Chinese) 